\title{
spinoza on children and childhood
}

\author{
noa lahav ayalon ${ }^{1}$ \\ university of haifa, israel \\ orcid id: https:/ / orcid.org/0000-0002-0764-6993
}

\begin{abstract}
Baruch Spinoza, the 17th century philosopher best known for his metaphysical rigor and the radical heterodoxy of his conception of God as Nature, did not say much about children or childhood. Nevertheless, his few mentions of children in his masterpiece, the Ethics, raise fascinating questions of autarky, rationality and mind-body relations as they are perceived in the contrast between children and adults. Generally, philosophical theories of childhood benefit greatly from a strong metaphysical foundation. Spinoza's philosophy, which has recently been gaining considerable attention by contemporary neuroscientists and psychologists, can serve as stable and fertile ground for developing a strong philosophy of childhood. In this paper I address the Spinozistic conception of a flourishing, happy human and the way this understanding of human excellence reflects on his understanding of children and childhood. I argue that the use of Spinozistic concepts can be valuable in the analysis of children and childhood-especially essence, striving to persevere in being, and the nature of the imagination. Spinoza's epistemology can explain the unique rationality of children, and provide a metaphysical basis for normative behavior. Moreover, it can help us as caregivers better understand and empathize with children, by explaining the similarities and differences between children and adults.
\end{abstract}

keywords: childhood; spinoza; human essence; ethics.

\section{spinoza sobre los niños y la infancia}

\section{resumen}

Baruch Spinoza, el filósofo del siglo XVII más reconocido por su rigor metafísico y la radical heterodoxia de su concepción de Dios como Naturaleza, no habló mucho de los niños ni de la infancia. No obstante, las escasas menciones que hace de los niños en su obra maestra, la Ética, hacen surgir preguntas fascinantes sobre autarquía, racionalidad y relaciones mentecuerpo, tal como son percibidas en el contraste entre niños y adultos. En general, las teorías filosóficas sobre la infancia se benefician enormemente de una sólida base metafísica. La filosofía de Spinoza, que últimamente ha estado recibiendo considerablemente mayor atención por parte de neurocientíficos y psicólogos contemporáneos, puede servir de terreno estable y fértil para desarrollar una sólida filosofía de la infancia. En este artículo, abordo la concepción spinozista de un ser humano floreciente y feliz y el modo en que esta comprensión de la excelencia humana se refleja en su comprensión de los niños y la infancia. Sostengo que el uso de conceptos spinozistas puede ser valioso en el análisis de los niños y la infancia - especialmente la esencia, luchando por perseverar en el ser, y la naturaleza de la imaginación. La epistemología de Spinoza puede explicar la singular racionalidad de los niños y proporcionar una base metafísica para el comportamiento normativo. Además, puede ayudarnos, como cuidadores, a comprender mejor y empatizar mejor con los niños, al explicar las similitudes y diferencias entre los niños y los adultos.

\footnotetext{
${ }^{1}$ Email: noa.lahav@mail.huji.ac.il
} 
spinoza on children and childhood

palabras clave: infancia; spinoza; esencia humana; ética.

\section{spinoza sobre os niños e a infância}

resumo

Baruch Spinoza, filósofo do século XVII, mais conhecido por seu rigor metafísico e a heterodoxia radical de sua concepção de Deus como Natureza, não diz muito sobre as crianças ou a infância. Contudo, suas poucas menções às crianças em sua obra-prima, Ética, levantam questões fascinantes de autarquia, racionalidade e relações mente-corpo percebidas no contraste entre crianças e adultos. Geralmente, as teorias filosóficas da infância se beneficiam muito de uma base metafísica forte. A filosofia de Spinoza, que recentemente tem recebido considerável atenção de neurocientistas e psicólogos contemporâneos, pode servir como um terreno estável e fértil para o desenvolvimento de uma forte filosofia da infância. Neste artigo, abordo a concepção spinozista de um ser humano próspero e feliz e a maneira como essa compreensão da excelência humana reflete em sua compreensão das crianças e da infância. Eu argumento que o uso de conceitos spinozistas pode ser valioso na análise de crianças e da infância - especialmente a essência, o esforço para perseverar no ser, e a natureza da imaginação. A epistemologia de Spinoza pode explicar a racionalidade única das crianças e fornecer uma base metafísica para o comportamento normativo. Além disso, pode nos ajudar, como cuidadores, a compreender melhor e ser empático com as crianças, ao explicar as semelhanças e diferenças entre crianças e adultos.

palavras-chave: infância; spinoza; essência humana; ética. 
the role of doubt in collaborative philosophical inquiry with children

\section{introduction}

There is an inherent tension in many Western philosophers' writing when they address children and childhood. Traditionally, childhood is a state that the human aspires to overcome ${ }^{2}$. The child is perceived as less rational than the adult, and he or she is deficient in the specific attributes that the philosopher holds as the most virtuous and valuable: moderation, propensity for abstract thought, selfsustenance and independence (both materially and mentally). But the child is also curious, prone to wonder (defined by Aristotle as the origin of philosophy), highly engaged with and able to absorb cognitive stimuli. Moreover, it is an inescapable fact that all philosophers were once children. It is a state they have outgrown, changed out of; it often seems that the philosophical preoccupation with selfimprovement and emendation of the mind subconsciously renders childhood as a necessary but unfortunate state that the adult is happy to exit. Therefore, it is a state that has not gained purposeful philosophical exploration.

Spinoza is a quintessential example of this state of affairs. His metaphysical and epistemological commitments are characterized by radical naturalization; therefore, insofar as they are natural and necessary, children and childhood should be an important and valid topic of study. But although children are mentioned in several passages of the Ethics, the child's mind (insofar as it is the mind of a human specimen, that does not fundamentally change its nature throughout the course of their life), is not studied exclusively. Nevertheless, the extrapolation of Spinoza's metaphysical commitments onto the nature of children can lead to interesting observations: on how we as adults perceive children, the ways we comprehend their challenges and aspirations, and the inner workings of their minds.

Even though Spinoza himself did not specifically point to children and childhood as important subjects of philosophical thought, I argue that as contemporary commentators, who have a more nuanced understanding of

\footnotetext{
${ }^{2}$ We find interesting exceptions in Plato's Lysis and Nietzsche's Thus Spake Zarathustra (in The Three Metamorphoses).
} 
childhood as a philosophical theme, we have much to benefit from thinking about children through the Spinozistic framework. Spinoza's insights on the mind, its mental processes such as learning, imagining and understanding, as well as the mind's ability to moderate the passions, can serve theoreticians in their philosophical analysis of what it means to be a child.

In the next part of the article, I will present the metaphysical tenets of Spinoza's philosophy. His metaphysics bear a direct implication on his theory of the human mind and the purpose of human life. These, in turn, can be straightforwardly perceived as manifested in children. But will Spinoza's mentions of children and childhood actually prove coherent with his general metaphysics? In the third part of the article, I will present the textual appearances of children in the Ethics. In the fourth and final part, I will comment on their consistency with the tenets presented in the first part.

\section{god or nature and mind-body unity in spinoza}

In the Ethics, Spinoza presents God or Nature as the unique existing substance. Everything we sense or think is a part of God-presented, as it were, as a mode of substance. All modes can be perceived through two attributes, of which humans are capable of perceiving, namely, extension and thought. Therefore, all things have a corporeal and a mental representation, which are two expressions of the same thing. A human being, for example, is one single thing whose expression in thought is a mind, and its expression in extension is a body. Therefore, mind and body are completely united in Spinoza's system, and they have no causal interaction between them. Every process or event that occurs in the human mode is represented in the body and the mind, with no exception. This theory has come to be known as "parallelism" (although this particular name has not been coined by Spinoza himself).

The essence of each singular thing is defined by Spinoza as striving to persevere in being (IIIp7)3. In the case of the human mind, this essence is

\footnotetext{
${ }^{3}$ All references to Spinoza's texts are from The Collected Works of Spinoza, vol. I, trans. Edwin Curley, (Princeton: Princeton University Press, 1985). When referring to the Ethics, a $=$ axiom, $d=$ definition, $\mathrm{c}=$ corollary, $\mathrm{p}=$ proposition, $\mathrm{s}=$ scholium (following a proposition reference, $\mathrm{d}=$ demonstration).
} 
understanding rationally; the action of the mind is understanding. The mind is powerful and virtuous to the extent that it is able to order its thoughts according to the order which exists in Nature. Therefore, understanding God consciously amounts to the greatest achievement the human mind is capable of in this life. This leads to the expected disparagement of children as deficient human agents - their perception of themselves and the world around them is far from the rational ideal held up by philosophy.

This is evident in Spinoza's remarks on the relation between bodily and mental ability, which appear in one of the earliest propositions on the matter, IIp13s:

[...] in proportion as a body is more capable than others of doing many things at once, or being acted on in many ways at once, so its mind is more capable than others of perceiving many things at once. And in proportion as the actions of a body depend more on itself alone, and as other bodies concur with it less in acting, so its mind is more capable of understanding distinctly.

This statement is echoed in IIp14, IVp38-9, and Vp39, for example. The mind's powerfulness is "measured" according to its essence, which is understanding; therefore, its ability to understand is the only relevant yardstick to its mental health or ability. Note the division Spinoza makes in the quote above between perception and autarky: a mind is capable of perceiving many things at once in direct relation to its bodily ability to perceive (compare, in Aristotelian fashion, the human five senses with those of a tree, a sea cucumber, and a cow). But our bodily senses, advantageous as they may be regarding our potential for perception, and therefore our capacity to think, do not necessarily bear on the human mind's ability to act according to its nature. This ability to act according to our nature, which is equivalent to our existence as a cause, has to do with self-dependence and therefore autarky. That is, being a cause, having agency in the world, means for Spinoza to act as independently as possible according to our nature - to contemplate rationally eternal, unchanging things. This is highly compatible with the traditional, Platonic ideal of philosophy.

Thus, "IIp40s2" refers to Part Two of the Ethics, proposition 40, second scholium; "Id4" refers to Part One, definition 4; "IVp18d" refers to Part Four, proposition 18, demonstration. 
The mind's health with respect to bodily affections (which represent its relation to external things) is not expressed by its direct effect on the external objects, but by its interpretive force regarding the external effects on itself. That is, the power of the mind, expressed in rational thought, is its power to order its affections according to its own nature, the intellect. The mind's powerfulness manifests itself in its reactions to external influence, and not by its control over them. Full control, of course, is de facto impossible. The extent to which a certain individual is powerful is the extent to which he or she acts according to their essence.

One's powerfulness directly tracts their joyfulness and virtue. In other words, the more powerful the individual, the better and more joyous he or she is. States, nonhuman animals and communities can also be regarded as individual things. In all cases, the most general definition of acting according to essence is to be adhered: essence is striving to persevere in being. Simply put, everything strives to persevere in being, but the way this striving is expressed is different in the case of different individuals. Lions aim to persevere in being differently than mice. For the human mind, which is the expression of the human being in the attribute of Thought, the essential act is to think. And thinking well means understanding; hence, what the human mind does in order to persevere in being is aiming to think well, understand and act rationally according to its understanding.

Since power is acting according to essence, in the case of humans the ability to understand oneself and the world adequately is expressed in the person's joy and morality. Conversely, someone consumed by hatred is a person who understands poorly and is simultaneously weak and sad. These expressions of power and essence serve as important metrics in evaluating people, behaviors and ways of life. A hateful person, nation or community is weak. A loving one is virtuous and strong. It will succeed in doing the thing God or Nature fundamentally dictates, namely, preserving its being.

Part II of the Ethics centers on a discussion of the human mind. A major issue that is analyzed and argued for is the mind's capability and proclivity to perceive things via the first kind of knowledge, or the imagination (also referred to as opinion). The mind is bombarded by various external affects, and it is not possible 
to automatically piece together every occurrence into a coherent account. Nevertheless, the natural human need to do so gives rise to myriad semi-rational mechanisms: superstition, mythology, or a belief in miracles (these issues are prominently discussed in Spinoza Theological-Political Treatise). Spinoza is quite unforgiving of these inclinations, as evident in IIp44, a hallmark proposition which presents Spinoza's determinism: "It is of the nature of reason to regard things as necessary, not as contingent". Although the mind is by nature guided by the rational principle of sufficient reason, it is also of its nature to be finite and limited, therefore unconscious of the reasons for every single thing. It is through this unconsciousness that the idea of contingency is born, aided by the necessary mechanism of the imagination.

Knowledge, for Spinoza, is an affective state ${ }^{4}$. There are three kinds of knowledge: opinion or imagination; rational thought; and intuitive knowledge. An idea in the mind, known or perceived via one of the three ways of knowing, has necessary effects on the general configuration of ideas in the mind itself (i.e., its general affective state). As Spinoza makes clear in his definition of affects (IIId3), insofar as they pertain to the mind affects are ideas (manifested as changes in the mind's power of acting). Passions, which are a subset of affects, are "confused idea[s]... which, when [they are] given, determines the mind to think of this rather than that" (General Definition of the Affects). Far from being inert, an affect has the necessary effect of prompting the mind to think of other ideas. The ideas of the affects, like all ideas, can be understood via the first, second or third kind of knowledge. This is because every idea in our mind is an idea that we know in some way; and the knowledge of these ideas vary in their clarity and distinctness. When we are subject to passions, the ideas in the mind which constitute these passions are confused and inadequate. Inadequate ideas are the root of all evil, according to Spinoza - they are the source of all discord, enmity and suffering in human beings. Moreover, subjectivity to passions and lack of self-determination represent together

\footnotetext{
${ }^{4}$ The intense correlation between knowledge and affects is the basis for Spinoza's understanding of human bondage (IVp8, IVp14, IVp15, IVp23, IVp26 ff.; as well as Vp7, Vp9, Vp11).
} 
the definitive human vice, and the greatest impediment to virtue, blessedness and freedom.

How do these metaphysical and epistemological commitments shape Spinoza's conception of children and childhood? In general, infants and children are notoriously not autarkic. They require constant care and safekeeping. But their natures are highly adapted to aid their perseverance in being. Infants, for example, use the means at their disposal, such as crying, cooing and clinging to communicate their needs and at the same time validate the worth and satisfaction of their caregivers. They create a symbiotic, often dyadic relationship that ensures their perseverance in being. Caregivers are rewarded physically and mentally for their care and connection through feelings of self-worth and affection (physiologically expressed as rushes of oxytocin and endorphins). But through Spinoza's analysis, the child is first and foremost a needy, deficient and underdeveloped specimen of a human.

Spinoza, like many Western philosophers before and after him, gravely underestimated the powerfulness of children; like slaves, women and the mentally challenged, children are perceived as sub-rational (and therefore, generally "less than"). In the following section, I will address the references to children and childhood in the Ethics, and question the validity of Spinoza's assumptions based on his general metaphysics and epistemology.

\section{children in the Ethics}

Spinoza evokes childhood when he gives an example which clarifies the establishment of imaginative thoughts, and the way in which imagination operates (IIp44s):

Let us suppose, then, a child, who saw Peter for the first time yesterday, in the morning, but saw Paul at noon, and Simon in the evening, and today again saw Peter in the morning. It is clear from p18 that as soon as he sees the morning light, he will immediately imagine the sun taking the same course through the sky as he saw on the preceding day, or he will imagine the whole day, and Peter together with the morning, Paul with noon, and Simon with the evening... and he will do this more uniformly, the more often he has seen them in this same order [...] But if it should happen at some time that on some other evening he sees James instead of Simon... 
His imagination, therefore, will vacillate and he will imagine now this one, now that one, with the future evening time, that is, he will regard neither of them as certainly future, but both of them as contingently future.

Imagination is a mental mechanism which is best explained through an example of children, it seems, because the reader of the Ethics will have trouble with finding fault in his own way of thinking - but won't have any trouble finding fault with the thought processes of a child. In a sense, Spinoza is agreeing with this judgment. But on further inspection, we see that Spinoza offers the example of the child as someone who is subjected to sensory experience and initially regards the information he has received as necessary. That is, following the perception of Peter in the morning, the child generalizes the incident and makes it a rule, expecting thereafter to see Peter every morning. But when that fails to happen, his mind adapts (i.e., vacillates), and learns to regard the appearance of Peter as contingent. This, claims Spinoza, is the source of error, since regarding things as contingent is an error in itself. It is important to note, though, that the child has only adopted the idea of contingency after his ultra-rationalist approach, which over-generalizes, has proved faulty. So the primal act of the child's mind in his striving to persevere in being was actually rational to a fault, as it were.

In IIp17s, in a direct discussion of the mechanism of the imagination, Spinoza claims that insofar as we are conscious of the mechanism of the imagination, it is not to be considered as a vice of human nature, regardless of the errors it engenders. That is, since the mechanism of the imagination is a feature of the human mind, as natural and necessary as any of its other features, and since no idea is false by any "fault" inherently its own, the imagination, understood adequately for what it is, may be considered a virtue of the mind ${ }^{5}$. The freedom of the mind (the practice of rational contemplation and the perception of true ideas) cannot be based upon an avoidance of error through the elimination of the imagination (which is the only

\footnotetext{
5 "...For if the mind, while it imagined nonexistent things as present to it, at the same time knew that those things did not exist, it would, of course, attribute this power of imagining to a virtue of its nature, not to a vice-especially if this faculty of imagining depended only on its own nature, that is (by Id7), if the mind's faculty of imagining were free" (IIp17s).
} 
spinoza on children and childhood

cause of error, according to Spinoza), but through an understanding of what the imagination is and how it operates.

The imagination is the mind's way of establishing connections between ideas whose true connections is doesn't adequately or truthfully grasp; and proper understanding is all the more difficult when these connections run contrary to sensory experience ${ }^{6}$. On the one hand, the mind's inability to understand things weakens it through feelings of dissonance, confusion and helplessness (i.e., forms of sadness). On the other hand, the imagination, which is to some extent a mechanism of psychological and epistemic self-preservation which aims to alleviate these feelings, is also harmful. The imagination produces superstition, for example, in an attempt to establish a sense of order in the world and serve the human in his or her effort to navigate the trials of life by giving a sense of control. But since the imagination isn't rational, the superstitions that it engenders will, in the long run, undermine the mind's ability to thrive and persevere.

Spinoza's negative judgment of the child's mental capacity relative to that of an adult is also evident in his reference to consciousness. He writes in Vp39s:

[...] he who, like an infant or child, has a body capable of very few things, and very heavily dependent on external causes, has a mind which considered solely in itself is conscious of almost nothing of itself, or of God, or of things. On the other hand, he who has a body capable of a great many things, has a mind which considered only in itself is very much conscious of itself, and of God, and of things.

As mentioned above, the capabilities of the body are taken here to be measured by autarky and not necessarily by the ability to have a productive effect on the environment. But an additional measure is introduced in this passage, namely, the degree of consciousness of the mind. For Spinoza, the term consciousness is not a

\footnotetext{
${ }^{6}$ An example for this is in Ip15s, where Spinoza answers why we so often mistake nature to be a plurality and divide quantity: “...we conceive quantity in two ways: abstractly, or superficially, as we [NS: commonly] imagine it, or as substance, which is done by the intellect alone [NS: without the help of the imagination]. So if we attend to quantity as it is in the imagination, which we do often and more easily, it will be found to be finite, divisible, and composed of parts; but if we attend to it as it is in the intellect, and conceive it insofar as it is a substance, which happened [NS: seldom and] with great difficulty, then (as we have already sufficiently demonstrated) it will be found to be infinite, unique and indivisible".
} 
robust notion which lies at the basis of a theory of mind (it is important to note that some commentators claim that Spinoza has no theory of consciousness at all7).

The term "conscious" first appears in the Appendix of the Part I, mentioned in opposition to ignorance: "...men think themselves free, because they are conscious of their volitions and their appetite, and do not think, even in their dreams, of the causes by which they are disposed to wanting and willing, because they are ignorant of [those causes]". Spinoza's use of "consciousness", consistently with this quote, is as a relative term. Although he does not explicitly state this, it is evident that consciousness is always of something; and it is invariably connected to affects. In the Definitions of the Affects at the end of Part III, Spinoza explains the reason he added consciousness to the definition of desire as essence and separated it from appetite in IIIp9 thus: "...from this definition (by IIp23) it would not follow that the mind could be conscious of its desire, or appetite. Therefore, in order to involve the cause of this consciousness, it was necessary (by the same proposition) to add: insofar as it is conceived, from some necessary given affection of it, to be determined, and so on". That is, in order to incorporate consciousness to the definition of desire, affects (which induce consciousness) and arouse desire, had to be mentioned. IIp23, referenced in the explanation just quoted, deals with the mind's knowledge of itself through the perceptions of the ideas of the body's affections. It is implied, then, that affections and their ideas bring about consciousness (which is synonymous with "mind's knowledge of itself"), and that this consciousness is not much more than awareness. This is also evident in IIp35s, which negates consciousness of actions and ignorance of causes.

So the child is, to a greater degree than the average adult, conscious of what he wants and unconscious of why he wants it. For Spinoza, this is patently problematic, because of the relation between unconsciousness of causes and the illusion of free will. As he writes in IIIp2:

most men believe that we do freely only those things we have a weak inclination toward... but that we do not at all do freely those

\footnotetext{
7 Some commentators claim that either there is a failed attempt at a theory of consciousness in Spinoza's work, or else that Spinoza's mentions of consciousness cannot form a coherent account. As Nadler puts it: "[I]t is generally believed that Spinoza... fails miserably to offer a coherent account of consciousness" (Steven Nadler, "Spinoza and Consciousness" Mind 117, no. 467 (July 2008), 575).
} 
things we seek by a strong affect... So the infant believes he freely wants the milk; the angry child that he wants vengeance; and the timid, flight. So the drunk believes it is from a free decision of the mind that he speaks the things that later, when sober, wishes he had not said. So the madman, the chatterbox, the child, and a great many people of this kind believe they speak from a free decision of the mind, when really they cannot contain their impulse to speak.

But it could be argued that although unconsciousness of causes does lead to a conception of free will in adults, this is not the case with children. Children, far more often than adults, frame their desires in terms of necessity ("I need...", "I must..."). In a sense they are more intuitively aware of the way they are driven to desire through necessity and by their automatic reaction to stimuli. Although children are not aware of the causes of their desires to the extent that adults, with experience, are aware of them, they are arguably aware of the force of the external stimulus relative to their own.

The child, much more conspicuously than the adult, is in a constant state of resistance and adaptation. In newborn babies this is especially evident. On the one hand, they are strongly determined by the nature of their bodies to act in certain ways, expressed in action through reflexes (what we term "non-voluntary" behavior; Spinoza would claim, of course, that all behavior is non-voluntary). On the other hand, they also learn new things about themselves and the environment constantly, and adapt, forming new habits and behavior patterns.

The general aim of Spinoza's discussion of the affects in such detail (the entirety of Part III and the addendum "Definitions of the Affects" which follows it), is to aid the consciousness of the causes of affects-affects of which all sentient adults are already very much aware. Pride and disdain, hate and pity, hope and fear are affects explained in this section through their necessary causes. In a passage that explains the nature of repentance (DefoAff 27), Spinoza specifically evokes childhood:

[...] it is no wonder sadness follows absolutely all those acts which from custom are called wrong, and joy, those which are called right. For from what has been said above we easily understand that this depends on education. Parents - by blaming the former acts, and often scolding their children on account of them, and on the other hand, by recommending and praising the latter acts - have brought it about that emotions of sadness were joined to the one kind of act, and those of joys to the other. 
In this passage, Spinoza explains moral conditioning by parents' habit of coupling the joy and sadness that accompany praise and blame with certain actions. But Spinoza does not necessarily commend this. The customs that dictate right and wrong are often ill-advised, according to him (see especially IVp37s, on the state of nature) and the superstition, hate and fear they engender are detrimental to rationality, well-being and perseverance in being. Repentance itself, explained in the passage presented, is nothing other than a type of sadness (necessarily leading to and amplifying weakness).

Pursuing the line of thought presented here further, we see that it is the parents that are responsible for weakening the child and creating erroneous moral sentiments. Although the child is rationally driven to please and learn from their parents, in order to survive, they suspend their own rational judgment in the process-judgment that is possibly much better suited for their perseverance in being in an ideal setting where society, as a whole, is rational.

Spinoza had a special word reserved for the mental and bodily state of the child, which he used only twice in the Ethics and consistently with reference to children: equilibrium. This is not a stoic state of equanimity; this is a state in which the inner and external forces pressuring the individual are equally forceful, and a constant state of balance is maintained. Generally, the individual strives through its aspiration for power and virtuousness to overcome its surroundings and express its nature. In Spinoza's understanding, the child, due to his or her underdeveloped rationality, does not have the ability to truly express their nature and overcome external forces. The derogatory meaning of equilibrium is presented in IIp49s, where Spinoza refutes the claim that free will is necessary, because without it the mind would not be able to escape states of equilibrium, such as in the story of Buridan's ass:

[...] I grant entirely that a man placed in such an equilibrium will perish of hunger and thirst. If they ask me whether such a man should not be thought an ass, rather than a man, I say that I do not know - just as I also do not know how highly we should esteem one who hangs himself, or children, fools, and madmen, and so on.

IIIp32s returns to the issue of equilibrium:

[...] if we wish to consult experience, we shall find that it teaches all these things, especially if we attend to the first years of our lives. 
For we find form experience that children, because their bodies are continually, as it were, in a state of equilibrium, laugh or cry simply because they see others laugh or cry. Moreover, whatever they see others do, they immediately desire to imitate it. And finally, they desire for themselves all those things by which they imagine others are pleased - because, as we have said, the images of things are the very affections of the human body, or modes by which the human body is affected by external causes, and disposed to do this or that.

Spinoza uses the notion of equilibrium in this passage to characterize children as almost solely reactionary (note the observation of children's propensity for mimicry - even when they do something, Spinoza doesn't attribute it to their own unique essence). It is true that a child is much more prone to express the effects that external forces have on them. A child may cry when they are hurt, physically or emotionally, and release the tension of the pain through tears, approaching a caregiver for a hug or some form of acknowledgement from their surroundings that something had occurred. The adult is characterized by internalizing the effect of the external force and not expressing their pain. Adults are commended for presenting an ability to overcome the effects of external injury, regardless of whether they had truly overcome the pain or whether they are merely stifling their natural responses (that is, whether they had truly reordered the mental affects rationally or not).

In the latter case, Spinoza would indeed claim that the adult is no better than a child. The aim of the Ethics, and therapeutic philosophy in general, is to use rationality in order to overcome the passions in a way that strengthens and empowers the individual, and doesn't weaken them through anger and hate (which are often the result of internalizing negative emotion). But since children express their pain in order to overcome it, it could be argued that by asking for help in processing their emotions, they are actually choosing the most rational way to deal with the situation. The problem with this argument is of course the rationalist requirement of autarky. But it should be noted that aside his touting of an autarkic ideal, Spinoza was very much aware of the need one has of others - even the human exemplar of the free $\operatorname{man}^{8}$. As he explicitly writes:

\footnotetext{
${ }^{8}$ The issue of the possibility of freedom, otherwise known as the possibility of the "free man", is the topic of lively scholarly debate. It is held by a great majority of commentators that the model of the free man introduced in Part IV is not practically attainable for specific humans; even worse, it a metaphysical impossibility (See Don Garrett, "Spinoza's Ethical Theory", in The Cambridge Companion
} 
There are, therefore, many things outside us which are useful to us, and on that account to be sought. Of these, we can think of none more excellent that those which agree entirely with our nature. For if, for example, two individuals of entirely the same nature are joined to one another, they compose an individual twice as powerful as each one. To man, then, there is nothing more useful than man. (IVp18s)

It remains to be examined, then, whether Spinoza should really have regarded children as so radically different from adults.

\section{is spinoza's position on children coherent with his general philosophy?}

A telling passage regarding Spinoza's nuanced stance regarding children and childhood appears in the scholium of IVp39. The proposition itself presents a theory of personal identity and its metaphysical reliance on what Spinoza calls a "proportion of motion and rest" which is unique to each individual and represents the relation between the parts he or she is made up of. As an example, he writes of a Spanish poet he heard of, who recovered from an illness that left him with no recollection of his past life, to the point where he did not recognize any poem or play he had written. Spinoza then goes on: "If this seems incredible, what shall we say of infants? A man of advanced years believes their nature to be so different from his own that he could not be persuaded that he was ever an infant, if he did not

to Spinoza (Cambridge, UK: Cambridge University Press, 1996); Herman De Djin, "Ethics IV: The Ladder, No the Top: The Provisional Morals of the Philosopher", in Spinoza on Reason and the "Free $M a n '$ ', ed. Yirmiyahu Yovel and Gideon Segal (New York: Little Room Press, 2004); Daniel Garber, "Dr. Fischelson's Dilemma: Spinoza on Freedom and Sociability", in Spinoza on Reason and the 'Free Man', ed. Yirmiyahu Yovel and Gideon Segal (New York: Little Room Press, 2004); Charles Jarrett, "Spinoza's Constructivism", in Essays on Spinoza's Ethical Theory, ed. M. Kisner and A. Youpa (Oxford: Oxford University Press,2014), Matthew Kisner, "Reconsidering Spinoza's Free Man: The Model of Human Nature", Oxford Studies in Early Modern Philosophy 5 (2010); Michael LeBuffe, From Bondage to Freedom, Oxford: Oxford University Press, 2010, 187-90). In a nutshell, the reason is our necessary existence as finite entities among infinite others, whose powers clash with our own, and who will eventually overpower us. If the free man is understood as someone whose mind is completely devoid of inadequate ideas, it is certainly the case that this is (under the aspect of duration), an impossibility.

In opposition to this stance, Nadler holds that the free man is a possibility precisely because humans are continually affected by external forces, and have these opportunities to overcome the passions and their harmful effects through an exertion of their essential power, namely, reason (Steven Nadler, "On Spinoza's 'Free Man.'” Journal of the American Philosophical Association 1, no. 1 (2015), 114). Insofar as the very choice of the term "free" suggests, this makes sense: if there was no bondage to overcome, freedom would not really be a coherent concept. In order to be free, we must be free of something; the existence of bondage is logically necessary and fits well with Spinoza's choice of words. 
make this conjecture concerning himself from [NS: the example of] others". This idea of the proportion of motion and rest as the unique formula of each individual is so radically endorsed by Spinoza, that he claims that a person does not have to become a corpse in order to die, or change fundamentally in terms of the nature of their existence (or lack thereof) - all that actually happens is a change in the proportion of motion and rest between the parts that make up his body and mind.

In this sense, Spinoza does indeed have a dual understanding of the nature of children. On the one hand, he does accept without question (unlike the "man of advanced years" he references in the quote above) that there is a personal identity that is retained in the passage from childhood to adulthood. On the other hand, he is reluctant to attribute the rational capabilities he could to children. For Spinoza, the child's mind epitomizes the weak rationality and the passivity of the imagination.

Since it seems that Spinoza's position on children is somewhat inconsistent with his general metaphysical psychology (ignoring the child's ability to persevere in being, as well as the rationality they exhibit in early years), it is interesting to try and trace its origins to other influences. The most obvious is the Aristotelean tradition', which views the child as an incomplete version of its ultimate telos, the mature adult. But Spinoza is famously adamant in his rejection of teleology (see especially his remarks on this subject in the Appendix to Part I and the Preface to Part IV). Judging the child as inferior according to standards that pertain to their future development fails to acknowledge the power of a child with respect to their natural abilities and situation.

The problematic status of the child in Spinoza's philosophy mirrors its status in the vast majority of Western philosophy. The main problem stems from the inability to characterize the child as human (which they obviously are, and therefore subject to the same standards as adults) and at the same time qualitatively different

\footnotetext{
${ }^{9}$ Spinoza has been depicted by H.A. Wolfson as the last great medieval philosopher (see Harry Austryn Wolfson, The Philosophy of Spinoza: Unfolding the Latent Processes of His Reasoning. New York: Schocken Books, 1969) and as a critical student of Maimonides (see Warren Zeev Harvey, "A Portrait of Spinoza as a Maimonidean." Journal of the History of Philosophy 19, no. 2 (1981): 151-72). His rich and complicated relationship to Aristotle has been the subject of a comprehensive French study (see Fréderic Manzini, Spinoza: une lecture d'Aristote. Paris: Presses Universitaires de France (2009)).
} 
from the adult. Appreciating the child's rationality, for example, seems to contradict their apparent passivity and immoderation. Granting childhood a special status in terms of powers and challenges seems to diminish from the glorification of the seasoned, accomplished adult (who is, without exception, the one who writes philosophy). It is important to note that the inconsistencies within Spinoza's treatment of children and childhood represent the problems in many other philosophers' treatment of the subject ${ }^{10}$.

And yet, although Spinoza does not explicitly pursue this method of theorizing about childhood, much can be gained from consistently applying his metaphysical insights to the subject of children. As we grow more aware of the powers and capabilities of children ${ }^{11}$, these can be understood through Spinoza's theories of striving-to-persevere-in-being and mind-body unity. The child's perceived lack of moderation, for example, is not necessarily the result of weak rationality or essence, but a rational response to a world with which they have little experience. To push this even further, we can claim that many learned behaviors such as restraint, fear of retribution and quelling curiosity in order to avoid annoying impatient adults are themselves weakening traits that society teaches the child. With the famous exception of Rousseau's Emile, the education of children exemplified in Western philosophy before the $20^{\text {th }}$ century was generally aimed at getting the child to conform with the adult world. This conformity was often expressed by the child's ability to demand the satisfaction of their needs in a way acceptable by the surrounding adults. In some cases, what children actually learn from this "education" is how to suppress their essence and ultimately weaken their own inherent nature. The delicate balance maintained by a good educator, between boundaries and the nurturing required to help a child flourish, was a neglected

\footnotetext{
${ }^{10}$ See especially Garreth B. Matthews, "Philosophy and Developmental Psychology: Outgrowing the Deficit Conception of Childhood," in The Oxford Handbook of the Philosophy of Education, ed. by Harvey Siegel, Oxford: Oxford University Press, 162-76.

${ }^{11}$ An example of such progress can be found in developmental psychology research, such as those centering on object-permanence. See Moore \& Meltzoff, "New findings on object permanence: A developmental difference between two types of occlusion". The British journal of developmental psychology, 17(4), 623-644 (1999).
} 
topic in philosophy. Spinoza is no exception to this rule-although his theory of essence has much to contribute to the topic.

In objection to my analysis regarding this lacuna in philosophical treatments of children and education, it could be argued that what children are actually taught is to moderate their passions, and that this is something Spinoza would definitely approve of. But is crying in order to procure milk a passionate response? Or is it simply the most effective (and therefore rational) way to persevere in being?

It would be erroneously anachronistic to try to answer these questions solely through Spinoza's philosophy, who clearly did not address them straightforwardly, but only in passing as examples or observations regarding children and adults' treatment of them. But given the great amount of attention Spinoza's mind-body theory is gaining recently, with its undeniable foresight regarding cognitive science and neurobiology $\mathrm{y}^{12}$, Spinoza's understanding of children could also be examined. And even if some conclusions run counter to his own specific remarks, the framework of his arguments is valid and stimulating.

\section{references}

Damasio, Antonio. Looking for Spinoza: Joy, Sorrow, and the Feeling Brain, Orlando: Harcourt, 2003.

de Djin, Herman. "Ethics IV: The Ladder, On the Top: The Provisional Morals of the Philosopher", in Spinoza on Reason and the 'Free Man', ed. Yirmiyahu Yovel and Gideon Segal New York: Little Room Press, 2004.

Garber, Daniel. "Dr. Fischelson's Dilemma: Spinoza on Freedom and Sociability", in Spinoza on Reason and the 'Free Man', ed. Yirmiyahu Yovel and Gideon Segal, New York: Little Room Press, 2004.

Garrett, Don. "Spinoza's Ethical Theory", in The Cambridge Companion to Spinoza. Cambridge, UK: Cambridge University Press, 1996.

Harvey, Warren Zeev. "A Portrait of Spinoza as a Maimonidean." Journal of the History of Philosophy 19, no. 2 (1981): 151-72.

Jarrett, Charles. "Spinoza's Constructivism", in Essays on Spinoza's Ethical Theory, ed. M. Kisner and A. Youpa. Oxford: Oxford University Press, 2014.

Kisner, Matthew. "Reconsidering Spinoza's Free Man: The Model of Human Nature", Oxford Studies in Early Modern Philosophy 5, 2010.

LeBuffe, Michael. From Bondage to Freedom, Oxford: Oxford University Press, 2010.

Manzini, Fréderic. Spinoza: une lecture d'Aristote. Paris: Presses Universitaires de France, 2009.

\footnotetext{
${ }^{12}$ See especially Antonio Damasio, Looking for Spinoza: Joy, Sorrow, and the Feeling Brain, Orlando: Harcourt, 2003.
} 
Matthews, Garreth B. "Philosophy and Developmental Psychology: Outgrowing the Deficit Conception of Childhood," in The Oxford Handbook of the Philosophy of Education, ed. by Harvey Siegel, Oxford: Oxford University Press, 162-76

Moore, M. K., \& Meltzoff, A. N. New findings on object permanence: A developmental difference between two types of occlusion. The British journal of developmental psychology, 17(4), 623-644, 1999.

Nadler, Steven. "Spinoza and Consciousness" Mind 117 (467), July 2008.

Nadler, Steven. "On Spinoza's 'Free Man.'” Journal of the American Philosophical Association 1, no. 1, 2015.

Spinoza, Baruch. The Collected Works of Spinoza, vol. I, translated by Edwin Curley, Princeton: Princeton University Press, 1985.

Wolfson, Harry Austryn. The Philosophy of Spinoza: Unfolding the Latent Processes of His Reasoning. New York: Schocken Books, 1969.

received in: 02.05 .2021

approved in: 30.11 .2021 